Kente: Cape Coast Journal of Literature and the Arts

Online ISSN: 2579-0285

https://doi.org/10.47963/jla.v2i1.99

\title{
Ayi Kwei Armah's Two Thousand Seasons: A Case Study Of The Epic Plot
}

Gladys Akua Agyeiwaa Denkyi-Manieson 


\section{AYI KWEI ARMAH'S TWO THOUSAND SEASONS: A CASE STUDY OF THE EPIC PLOT}

Gladys Akua Agyeiwaa Denkyi-Manieson Department of Communications and Languages Studies

Central University, Accra, Ghana

\section{ABSTRACT}

This work examines the plot of Two Thousand Seasons as an epic plot. The work contends that contrary to the popular belief that an epic narrative is a new form in Africa, epic narratives have long been known in African literary cycles. There are many models on the Epic analysis, but in this work, Albert Sackey's eight-part division of the epic plot as identified by Aristotle is used in this analysis. In the Poetics, Aristotle identified five elements of an epic: plot, character, setting, diction and thought. Two Thousand Seasons is subjected to an epic plot analysis. In analysing the epic plot, Albert Sackey's eight-point parts of the epic plot, which he refers to as "structural devices" of the Epic: the unity of time and action, Deux ex Machina, in medias res, opening invocation, extensive geographical travelling, catalogues of troops, digressions and division of texts, are used in this analysis.

\section{ARTICLE HISTORY}

Received: 11 March 2021

Accepted: 19 July 2021

\section{KEYWORDS}

African literature, epic, plot, narratology, godhead, in medias res

CONTACT: Gladys A. A. Denkyi-Manieson email: amanieson@cenral.edu.gh 
KENTE, 2021

Vol.,2 No.1

\section{Introduction}

The position of epics of African origin is a matter of debate among scholars. Ruth Finnegan (1970) observed that "...epic poetry does not seem to be a typical African form" (108-9). Also, in the African Epic, Lilyan Kesteloot (1989) notes that the African Epic is a subject that is not widely known by African studies specialists of West Africa but is still less well known in the northern hemisphere (1). MM Mulokozi believes that Ruth Finnegan's charge far from being a denigrating piece rather gingered research into African epics (1). The just stated is evident in the numerous critical works that emerged following Finnegan's observation. Mention could also be made of Bird (1974), Biebuyck (1972, 1976, 1978), and Okpewho (1977, 1979). For instance, Daniel Biebuyck (1976) points out in The African Heroic Epic that "published documentation on African Epic is limited and sometimes sketchy" (54). The lack of readily available documentation might have influenced Finnegan and Kesteloot to draw the above-stated conclusions. However, the genre of the Epic has been associated with African people since time immemorial.

Daniel Biebuyck further explains that two critical epic traditions exist among African people. One is among the Mende-speaking people of West Africa, and the other is among the Bantu-speaking groups of Central Africa (55). The Mende-speaking group includes the Mandeka, Bambara and Soninke. The Bantu speaking group consists of the Sotho of South Africa, the Swahili of East Africa, the Benamukuni of Zambia and the Ijaw of Southern Nigeria. Among the Mende speaking groups of West Africa, the famous epics include; The Manzon Cycle of the Bambara (Dumestre 1980), The Silamaka Epic of the Fulani and The Sundiata Epic of the Mandeka Niane 1960, Diabata 1975,). The Bantu - speaking groups have The Mwindo Cycle of the Banyanga (Biebuyck, D. P. and Mateene 1969), the Lianja Epic Cycle of the Mongo (Mubima 1999), the Mubila Epic of the Balega (Zaire Republic) and many others. The Mwindo Epic and the Epic of Sundiata, especially the former, are regarded as archetypes of African historical epics.

Keslelook, cited earlier, also identified two epic types in Africa; the Feudal and the clan epics. In her understanding, the Feudal epics are distinctive of societies organised into hierarchical professional "castes bearing 'mutatis mutandis' with features analogous to those of European feudal societies" (206). These epics are closely linked to heroes and are a good source of African historiography. She further compared them to European epic poems with the following elements, "one or several heroes around a king or prince, political clashes resulting in wars, 'Homeric' fights, an apologia for valour, the exalting of the group involved in the triumphant or tragic outcome, and lofty deeds which leave their stamp on the collective awareness by giving shape to its system of values" (205). On the other hand, the clan epics are always very long narratives punctuated by musical accompaniment enumerating the exploits of a heroic figure (207). They often present marginal and asocial individuals as heroes. These epic narratives speak of empires, heroes, hunters, kings and warriors. It is interesting to know that both types of epics have been associated with African people since time immemorial. However sad, as Biebuyck makes clear, is the absence of scholarship on this all-important genre. In light of the above revelations and more, an epic analysis 
of a text like Two Thousand Seasons is essential. Ayi Kwei Armah's Two Thousand Seasons adds to the data on African epic narratives and provides a glimpse of the colonisation process and the events after that.

In The African Epic: A Means for Defining the Genre, Christine Seydou opines that the African narrative epic provides two vital contributions to studying the epic genre in general. First, the Epic remains a living, spoken act of expression in those societies where orature is still in vogue. Therefore, its functions, and total expression can, thus, be observed in its natural setting. Second, comparing the cultural similarities and especially the variations found in entirely different cultures should reveal those distinctive qualities inherent in the epic genre in general (49). These also attest that the Epic is and has since time immemorial been an integral part of African oral narratives. It is, therefore, a matter of concern that critical literary study, especially African studies, has not paid keen attention to scholarship on this genre.

In chapter XXIV of The Poetics, Aristotle explained that the Epic possesses five of the six elements of tragedy. These are plot, character, setting, diction and thought. Among these elements, Aristotle considered the plot (mythos) as an essential component in an epic. He called it the 'underlying principle of tragedy'. This work focuses solely on an extensive analysis of the epic plot in Ayi Kwei Armah's Two Thousand Seasons. To do so, we employ the eight-part divisions of the epic plot as identified by Albert Sackey (2010) in Dimensions of Comparative Literature. He called the eight-part division of the epic "structural devices of the epic plot". These are: the unity of time and action, an invocation of the gods or muses, extensive geographical travelling, visit the underworld, a catalogue of troops before a battle, and in medias res (52-53). In addition to these, digressions and division of the text are also vital features of the epic plot. The scholarship is saturated with several analyses on the genre of the Epic. However, in this work, we shall limit the theoretical study to Aristotle and Sackey's analysis of the epic plot. Aristotle, because his theory has been predominantly used and suits the intention of this work. Besides, his definition is timeless. Sackey's also, because his analysis falls in line with Aristotle's prescription of the epic plot. It needs to be reiterated that this work aims to ascertain how Two Thousand Seasons fits in or otherwise employs the plot structure of an epic. Also, the work seeks to contribute to and "give the considerable corpus of African epic literature its true eminence in world literature" (Kesteloot 211). Other sources may be used to bolster the points raised. The argument herein is that the sequence of events in Two Thousand Seasons conforms to the definition of the Epic as explained by Albert Sackey. Also, the study reveals that in Two Thousand Seasons, Ayi Kwei Armah creates an African Epic narrative with a particular focus on the group's activities.

Ayi Kwei Armah is the author of several creative works: The Beautyful Ones Are Not Yet Born (1968), Fragments (1970), Armah, Two Thousand Seasons (1973), The Healers (1979), Osiris Rising (1995), KMT; the House of Life (2002), and The Revolutionaries (2013). However, Two Thousand Seasons seems to have enjoyed a wider readership and international review among these publications. The reasons for the wide acclaim are not far-fetched, great artistry. Wole Soyinka 
(1976), for example, referred to Two Thousand Seasons as "a visionary reconstruction of the past for social direction" (106). Soyinka's view is reiterated by renowned Ghanaian oral artist Kofi Anyidoho who hails Two Thousand Seasons as a united Africa's reconstitution, a vision of all people of African descent as one people (25). Other critics regard Two Thousand Seasons as a conglomeration of African literary work (Francis Smart-Ngaboh 2000, Mensah, 1991, Nwahunaya 1991). Smart-Ngaboh calls it a text about history, politics, identity, or about the post-colonial writer's indulgence in the ongoing mandate for self - legitimation. Smart adds that the novel seeks to unite Africans as a community (176). These sampled reviews are an endorsement of the literary value of the text in consideration. Again, Lief Lorentzon (1997) argues for the 'epicness' of Two Thousand Seasons through Armah's extensive use of the 'we' narrator (2). In Lorentzon's view Armah's consistent use of the first person plural, "we" gives an indication of a Pan African approach to African affairs, which in itself is characteristic of modern African Literature with epic qualities (230). The above comments notwithstanding, Bernth Lindfors (1992) thinks otherwise. He believes that Two Thousand Seasons is a philosophy of paranoia, anti-racist racism - in short, negritude reborn" (271). Lindfors adds that in place of usable historical myths, Two Thousand Seasons over-schematises the past, creating the dangerous kind of life. Lindfors' argument may not be out of place as it adds to the beauty of diversified reviews on the text under consideration.

\section{Synopsis of Two Thousand Seasons}

Two Thousand Seasons is a narrative of the encounter between people of African descent on one hand, and Arabs and Europeans on the other. This narrative provides a chronicling of activities that led to the disintegration of African people. In this narrative, the Arabs, the first foreign group to enter African states for trade, later turned the business relationship into one of slavery and constant brutalities, with the Arabs as masters and the African people as slaves. However, the Arabs were driven away through the collective efforts of some African women. Not long after that, with the connivance of some Africans, the Arabs returned to launch total swing on the Africans. Unable to live with the brutalities unleashed on them, the Africans migrated to find newer settlements around West, Central, Eastern and Southern parts of Africa. Unfortunately, no sooner had they settled in their new locations than they were confronted by another set of colonising agents from European nations, who captured many Africans and transported them to work on plantations overseas. Initially, a group of twenty young women and men rebelled against enslavement. These young people, collectively called the Initiates killed their king under whose reign the western colonialist advanced and consolidated their stay. The slain king Koranche was succeeded by his son. The seat of the white colonialist who was driven out was also taken over by Kamuzu, one of the freedom fighters. The narrative ends abruptly, with the fighter turned neocolonialist still in power. It is around this historical event in African history that the plot of Two Thousand Seasons revolves. However, this narrative, unlike any other, provides solutions to the Africa's problem. The following discussion focuses on the structural devices of the plot as outlined by Sackey. 


\section{Unity of Time and Action}

The idea of time is critical in Two Thousand Seasons, and this is obvious in the title of the text. The opening sentence, "we are not a people of yesterday", gives an idea of the use of anterior time in the narrative (1). By implication, the logic in "Two Thousand Seasons" also points to a posterior time. The dual timing refers to being "both backwards-looking and forward-looking" ( Nwahunanya; 550). The time sequence adheres to the Aristotelian principle that time in epics should not be limited. The title implies two thousand years of servitude, that is, one thousand years going into slavery and the other thousand years crawling out of slavery (17). Often, the time sequence in the text has been referred to as two thousand years of Africa contact with imperial powers (Ato Sekyi - Otu: 1). That is entirely erroneous because a historical interrogation of the time and action in the text proves otherwise.

The first thousand years began when the Arab traders were willfully accepted among the local folks. Historically, the first Arab invasion of Africa took place in 647 AD (Durant 1950). A thousand years after that comes to the year 1647 when colonisation was at its peak. Not long after that, in 1884, most African countries were partitioned for imperial rule in Berlin. Trade in slaves and mineral resources was booming. Three centuries later, the first country south of the Sahara, Gold Coast now Ghana, gained her independence from British imperialism. By fifty-four (54) years, all African states had gained independence. The first being Ghana and the last being South Sudan in the years 1957 and 2011, respectively. This shows that African nations still have some 636 years to put their houses in order. This is because the second thousand years comes to an end in the year 2647, by which time African nations would have been 'developed'. That is the import of the title, "Two Thousand Seasons". As the book of Revelations in the Bible, Two Thousand Seasons is a prophetic book that predicts the destiny of African nations. Armah's use of time is unlike any of the major epics; the action in the Trojan war took ten years, The Odyssey took ten years, The Aeneid took seven years, and that of La Chanson took about seven years (Sackey 53). Only Armah's Epic expands over a relatively longer period. However, when the ideology in the text is paired with the historical background of the events, a meaning emerges. Again, the action in the text centres on the total liberation of people of African descent, which to date is ongoing.

\section{Deux ex Machina}

First used by Aristotle in The Poetics, Deux ex Machina refers to the intervention of the gods in the affairs of men. This is very characteristic of epic plots. In Dimensions of Comparative Literature, Sackey explains that the intervention may manifest in four different forms. First, is the intervention of individual gods in the affairs of their favourites against their enemies; this may be executed in the form of dreams. Second, the intervention may be executed by a council of gods who meet to debate the affairs of men. Third, the intervention may be the inevitable workings of fate. Fourth and finally, is the presence of God (29-34). The import of all these is to emphasise the 
religious dimension in epics. A close reading of Two Thousand Seasons reveals the intervention in two forms out of the four identified by Sackey.

In the first place, we see the workings of the gods on behalf of their favourites as against the foe. Three characters were identified in the text; the African people, the Arabs and the Euro-Christian missionaries. Whenever these clashed or were engaged in any form of confrontation, the Africans emerged victorious. For instance, many years before the younger Anoa was born, we read of an older Anoa possessed by a spirit hating any form of servitude (14). That spirit possessed her earlier ancestors too. She hated subjugation of all kinds and brought patriarchs' wrath on anyone who would press anyone else into servitude. On the night of 'slaughter' with almost one hundred Arabs murdered, the women who carried out the act were aided by the spirit that possessed Anoa. These women, Azania, Sekela, Nywele, and many others, and with the help of a Canker, boldly rid their society which had been plunged into near death (21-25).

Again, when possessed, Anoa spoke of things that "filled the elders with chagrin" (15). She prophesied of "death of the body, death of the spirit, the death of single lost ones, death of groups snared in some killing pursuit, the death of nations, fiery extinction, destruction among ashes and voracious white conflagrations..." (15). And warned her people against "generosity of fools". Instead, she encouraged them to "return to the way, the way of reciprocity" (16). The same spirit prophesied of "two thousand seasons of slavery, a thousand being in it and a second thousand crawling maimed from it" (17). These prophecies are all manifestations of the aid of the gods on behalf of their chosen group, the African people, as against their oppressors, the Arabs.

Further, when the emigrating African people had a moment of confrontation on the bogland during which three pathfinders were killed, Nangome and Noliwe, possessed by a spirit, led the people to their peaceful settlement near the sea (52-56). It seems the gods had a personal interest in seeing the oppressed people settled in their new home against all the odds.

Secondly, we see the inevitable working of fate in the lives of the captured slaves in the text. Initially, some twenty young initiates were arrested from Anoa. Had they been taken alone, seizing the slave ship would have been difficult, if not impossible. However, by fate, they were mixed up with other slaves from other places with expertise in skills that were invariably brought to bear when needed most. For example, Sobo used a song to call others to seize the keys to unlock their chairs (138). Then, after securing their freedom, we read:

thirty cut wood and softened earth for building resting places. Ten brought grass for thatching, thirty took grain brought from the ship, sharpened fifteen stakes and planted corn from the day's middle to the falling of the welcome sun. Seven, the seven whose knowledge of the art of carving was surest, searched the surest surrounding forest for good wood....seven more searched the forest for familiar food and brought back the yellow yam. (138) 
Besides these and more, we read that, when language use was confusing, the experts began to teach them all the language of common choice, and before the next moon, they were not strangers to each other's tongues (144. Emphasis mine). These people made a perfect group; nearly everybody could do something. This is part of the divine intervention of the gods.

From the above, it is evident that the text is saturated with divine intervention. This enhances the epic nature of Two Thousand Seasons.

\section{In Medias Res}

Another element of the epic plot is 'in medias res', that is, the plot beginning in the middle. In Arts Poetica, the Roman poet Horace was the first to use the term to describe the work of an epic poet; he wrote, "but always he hurries to the action, and snatches the listener into the middle of things. (Poetic Arts, c. 13 BC). Great epics have featured this crucial element of the epic plot. Homer's Odyssey opened when the actual journeys of Odysseus were nearly over. Through various flashbacks, the entire story is retold. Also, Dante's Divine Comedy opens midway through the narrative, then with interior and exterior prolepsis and analepsis, the whole narrative is told. Again, Homer's Iliad begins with the quarrel between Achilles and Agamemnon during the Trojan war. Aristotle's admonishing notwithstanding, on the opening of the African Epic, Biebuyck notes that:

The epic traditions are pretty much open-ended. One performer may start with many preludes and introductions, tracing the origins of the heroes and the antecedents of the events and actions and introducing elaborate genealogies and cosmologies. Another performer may begin in medias res, with a vital event or activity that leads right into the main action, without bothering about preliminaries and other explanatory materials. One performer may focus in great detail on certain episodes and heroes, omitting or barely suggesting other events and characters. Another performer may indulge in numerous digressions of all sorts, praising his hosts or himself, alluding to personal experiences, and introducing anecdotes, explanations, philosophical and moral reflections. Some bards delight in detailed descriptions of councils, divination and healing scenes, speeches, conversations, and verbal challenges. Others pass rapidly over such points, to ensure a steady flow of action. (51, emphasis mine).

Biebuyck suggests that the African epic plot may not necessarily start in medias res because of its dual function. The Mwindo epic, for instance, begins as a traditional folktale; "A long time ago in the state of Ihimbi, there lived a king named Shemwindo who ruled the village of Tubondo...". The Epic of Sundiata also begins similarly. The beginning reads; "listen then, sons of Mali, children of the black people, listen to my word, for I am going to tell you of Sundiata, the father of the Bright country, of the savannah land, the ancestor of those who draws the bow, the master of a hundred vanquished kings..." (5). None of the above African epics begins in medias res because of its oral nature. 
Armah's opening sentence, "we are not a people of yesterday", is not any different from The Mwindo and The Sundiata Epics (1). In Two Thousand Seasons, it is obvious the author takes a great deal of time tracing the genealogy of the subject of his interest. The poetic prelude to the text eulogises evil mishaps that await the black people due to their encounter with the West. It is interesting that in this narrative, the main actors or characters are introduced after nearly a third of the text had been spent on tracing the genealogy of the African predicament. Unlike Aristotle's admonition, Two Thousand Seasons does not start in medias res. The narrative instead tells a narrative of a group genealogy that was on the verge of extinction. Armah's opening technique is what Christian Seydou calls "ideological reinterpretation of facts" (44). She is, further, of the view that the sequence of "epic is not destined to reproduce and transmit history chronologically as it was in reality and the causative sequence of facts, but rather that it is projected toward a cultural or ideological reinterpretation of these facts" (46). Therefore, whether the narrative starts in the middle or not is not a cause for concern for the narrator of this tale.

\section{Opening Invocation}

Also, Aristotle admonished the invocation of the muse in the Epic. In The Poet Appeals to His Muse: Homeric Invocations in the Context of Epic Performance, Elizabeth Minchin (1995) explains that in Greek mythology, nine muses were the goddesses of various arts such as music, dance and poetry (21). They primarily aided both gods and humanity to excel and to forget their troubles. They enabled musicians and writers to attain greater creative and intellectual heights. The invocation begins the epic poems and acts as the prologue to the events to come. The poet begs for inspiration, knowledge or the opportunity to finish a poem worthy of its subject matter.

Hesiod the Greek writer, for instance, claimed in Theogony to have held a conversation with various muses who blessed him with a divine voice to transform from a pure shepherd into a great poet at the pleasure of the gods. A close reading of Two Thousand Seasons reveals that Armah repeatedly invokes the Godhead in the text. In the first place, Anoa we read was "possessed by a spirit hating all servitude, so fierce in its hatred it was known to cause those it possessed to strangle those - so many now - whose joy it was to force the weaker into tools of their users" (14). That spirit had possessed Sekela, Azania and the other women who slew the predatory tormentors. When possessed, Anoa's spirit uttered prophecies of fiery extinction, destruction and voracious conflagrations. It also spoke of saltwater washing thousands upon thousands of dead people. She cautioned the people against "the generosity of fools" and prophesied the following against them:

Slavery - do you know what that is? Ah, you will know it. Two Thousand Seasons, a thousand going into it, a second thousand crawling maimed from it, will you everything about enslavement the destruction of souls, the killing of bodies, the infusion of violence into every breath, every drop, every morsel of your sustaining air, your water, your food. Till you come up again upon the way (17). 
In both prophesies, the African belief system functions as the voice that predicts and instructs the group members on the direction of their lives. These voices and utterances, Mtshali Khondlo believes, are entrenched deeply in African Traditional Religion. He thinks that when an emerging image has chosen its purpose in the traditional religion, an oracle or divine messenger announces this being's destiny. That was the case in Kunene Emperor Shaka (1981b) and D.T Niane's Sundiata (1965). The aforementioned is what is replicated in Two Thousand Seasons when it takes the priests and priestesses to announce the life purpose of the people of Anoa, the announcement of which was pronounced in seven voices. The first three spoke of a "time impending, a time heavy with courage. Fire, and in fire, blood hissing out of its life (12). The remaining five spoke of "fantastic journeys overland, on long, incredible traversing of a place neither land nor water...". Khondlo Mtshali also believed that the African belief system puts the priests and priestesses as agents or media through which communication with God Almighty and humans is facilitated.

Again, Dzobo argues that Armah invokes the godhead through an interplay of gender elements in the texts. Dzobo posits that the high God of the Ewes of West Africa is divisible into twin siblings "Mawu Sogbo" (female) and "Mawu Lisa" (male), a sort of a hermaphrodite divinity (228). The female 'Sogbo' is represented by the moon, and the male 'Lisa' is also represented by the sun. This view is further shared by the Akan of Ghana, who also believe that God is male and female; "Otwereduaampong Kwame" and "Asaase Yaa". The earth goddess, called "Asaase Yaa" by the Akan of Ghana and "Ani" by the Igbo of Nigeria, is the second most crucial deity among these tribes. The Ga-Adangbe call God "Ataa naa Nyogmo", literally translated, "God who is both man and woman". There is no doubt that most African societies have such a dual conception of God. This is what is implicated by the man-woman rule in Two Thousand Seasons. The rule of women we read was a period of peace because the women were "maintainers", "protectresses", "finders", and "growers", while that of the men was characterised by "violence" (10,11). According to Mbiti (55), the Akposso of Togo hold the belief that contrary to the Biblical belief, the woman was the first human to be created.

Additionally, through various water forms, Armah invokes the Godhead in Two Thousand Seasons. In the first sentence of the prologue, the word "water" is used three consecutive times. Besides this, various water forms are invoked in the text, emphasising the importance of water in religion. For instance, in Gods and Myths of Ancient Egypt, Armour explains that ancient Egyptians believed that life originated out of the antediluvian waters called Nun. Moreover, Kunene, cited earlier, believes that the ancient Amazulu Kingdom of Southern Africa thought that human life arose from the banks of a reeded river (3). Both etymologies associate life with a water source. Further, in Women in African Traditional Religions, Kenneth Kojo Anti observers that:

All over Africa, water bodies like the sea, rivers, lakes and lagoons are regarded as the habitats of deities and are thus treated with great reverence and sometimes worshipped at a shrine with specially appointed priests and priestesses (15, emphasis mine). 
The above reiterate that the image of water has a strong spiritual connotation that Ayi Kwei Armah brings to light in Two Thousand Seasons. Besides, in the religions of the world, water plays vital roles. For instance, Christians regard both holy water and the River Jordan as divine. In Sikhism, "Amrita", a water source, is considered to be divine. Lourdes to the Roman Catholics has spiritual benefits. In like manner, the river Ganges according to Hindus, is a unique source of spiritual healing. Finally, in Islam, the Zamzam well is said to be a source of holy water. Therefore the "spring water" and all other forms of water are images of the Godhead being invoked in Two Thousand Seasons.

\section{Extensive Geographical Travelling and Adventures}

On the nature of epic, Daniel Biebuyck explains that “... all epic-producing ethnic groups have elaborate traditions of migration, expansion and cultural assimilation, or well-established traditions of conquest" (49). Long adventures over a period mark the Epic. For over a decade, Homer's Odysseus travelled some fourteen different places before finally landing in Athens, his hometown, where he had a respite. The places he sojourned included Troy, Ismaros, the land of the lotus-eaters, the Island of the cyclopes, Aeolia and many others. The activities of the group in Two Thousand Seasons is marked by migration over a long period. Armah described them as "a people in motion" (49). The text is characterised by a journey spanning many years. Armah mentions that it took the group a "hundred years" moving from one place to the other before they could find a permanent place to settle (50). This section examines the journey motif as a significant feature of the epic plot in Two Thousand Seasons. It could first be explained that the group's migration was occasioned by the brutalities they suffered at the hands of their visitors turned hosts, the Arabs. With help from the hunters, the black women were able to ward off the Arabs when the Arabs turned to abuse them. However, the narrative shows that after a short while, with help from some black people, the Arabs returned and made slaves of the Africans. Unable to bear the brutality and hostility, they emigrated "seeking unknown soil to be true to the way" (39). The emigration brings out their adventure. They passed through numerous towns and villages.

Firstly, after journeying on foot for three days, they came upon a warm group of people who heard their story and empathised with them. Armah describes this first group as "gentle people", who "were numbered with calamity, unable to decide to break the habits of sedentary ages" (21). These hosts had nothing to offer because their harvest had been bad, so they did not have enough food themselves. Besides, they had also been beset by the callousness of people from the desert place who attacked them, killed many of their kin, robbed them of their food supplies, leaving them with virtually nothing to live on (46). However, these people had abundant white water, which they offered the group in flight. This first group of people spoke a language which the emigrants "understood with little difficulty" (46). Eight days after departing from the first group, they passed through several habitations that had become non-existent. Further on their journey, they passed through some twelve villages that had all been "destroyed, burned completely by some vengeful horde" (46). 
Moving further, they came upon a larger town, yet the entire place was empty. These towns were all burnt down utterly such that what was left was only a "charred husk" with no creature alive in these lands (47). We read, "death had visited this place, and had passed over it. There were no corpses, only skeletons" (47). In this large town, the devastation and plunder were so severe that the baobab, a tree widely known to withstand difficult climates, was rendered leafless with all its branches dead. The phrase "desolation so complete" (47) connotes the idea of total bleakness, sterility, and despondency. The complete desolation can be juxtaposed with the phrase "weakened all our spirits" (47). This scene of devastation so affected the group that the women gave in to "wailing loudly" (47).

Further, they met with the "two hollowed eyed maniacs"(47) on their journey, who instantly attacked them and killed two members of the group and wounded a few. When strung and calmed, these two told of the brutal attack on their people by white people from the desert who had "pillaged everything, killed men, enslaved the rest and transported them across the desert" (47). This action created in the manic an "overpowering hatred" towards humanity such that they instinctively plunged on the first human who came their way, being the group, killing two of them and wounding quite a few. The effect of the brutal attack on them was so severe that they begged the group to kill them. However, upon consultation, the group took them along on their journey; unfortunately, they did not survive and died shortly after. The maniacs are symbolic of the African after colonisation. Violence in African countries reached an all-time peak level after colonisation. The histories of Rwanda, Sierra Leone, Nigeria, Burundi, Ivory Coast, and many others attest to the effects of colonisation on the African people. Moreover, as to why just those two were left behind is not too far to surmise. A "hollow-eyed manic" (48) is a form of bipolar disorder that may either be euphoric or dysphoric. Several studies attribute the underdevelopment of Africa to the slave trade. Strong abled men and women were carried across the Atlantic while weak, invalids and older adults were left behind (Lovejoy , 28). Such is the case of the two manic who were left behind. Having experienced the above-described atrocities, they turned on "a new route" to a land Armah describes as "inhospitable land" (48). However, the new route did not bring them any new experience. They encountered several hostile villagers who lived on hilltops, hated strangers and refused to offer any help to the group, not even trading with them. These hilltop groups were described as being in an "impregnable position" (48), due to which they assaulted the group members. That phrase "impregnable position" connotes the idea of non - defeatist group or an influential group. Though the nationality of these hilltop group was not stated, it can be gleaned that they were fellow black people who had learnt to secure their environment from invading hostilities. They saw themselves as a separate group that would not want to offer any form of help to suffering African people, giving an idea of the division brought about by colonisation and slavery. Like the hollow-eyed maniacs, the hilltop group lost trust in humanity and saw any other group of humans as enemies who must be attacked and, if possible, treated with disgust.

Further on the journey, they encountered a rather pleasant group of people at the foot of the mountain. These traded freely yet, "drove a bargain without mercy" (47). The expression "without 
mercy' indicates the fierce, vicious, merciless and aggressive nature of the inhabitants at the foot of the mountains. Compared with the hilltop group, these seemed better yet had strings attached to their congeniality. Then they moved on in a "scattered way" and came upon a "strange territory". A land abundant in "unwanted fertility" and water good enough for drinking. The people were "shy people with an easy train of life..." who knew how to farm but did not practice it with any severe care (48). They found many groups of equally pleasant people who engaged in some form of farming at this rather pleasant place but not on a commercial scale. They built dwellings along the way and stayed, all the while making plans of venturing further for a hospitable place of abode (49). Herein lies Armah's solution to the African problem. To him, it is when African nations unite that they can survive as a group. The group stayed in this place for a time and then acting on the pathfinders' advice continued the journey. The pathfinders had been sent earlier to locate suitable lands where the group could settle permanently. Most of them returned with bad news. Only one group returned with news of an appropriate land beyond the bog land. Carefully, the group moved on through the bog land, intermittently stopping to rest. They encountered wild and more massive crocodiles, which snapped at them on the bog land. There were also water snakes which killed most of them daily. The narrator said, "the farther we journeyed, the worse the terrors awaiting"(52). The people regretted having made the journey and wished to return to the last village they left behind. Eventually, one pathfinder, Ndile, informed the group that they had lied to them and that there was no suitable land beyond the bog. This infuriated the people so much that they pounced on the pathfinders and killed them instantly. Noliwe and Nangome, two ladies in the group, wanted to save the pathfinders, but the others overpowered them and killed the pathfinders. When they recovered, they led the people to the place near the sea, which became their permanent home. That ended the adventure of the journey of the group to find a settlement.

It needs to be explained that the emigrations of the African people bring out the utopian dimension in the text. The utopian impulse seeks to create a perfect world free from the ills of society. This vision of a perfect world urged the oppressed African people to seek greener pastures. Ashcroft Bill reiterates the view that without a sense of utopianism, liberation is impossible (12). To be free from any form of oppression, the group had no option than to submit to utopian ideals. Yet, as noted by Mark Tabone, " ideas of "paradise" negate themselves at the very moment of conception"(48). When the Africans thought they had got rid of any form of oppression and found paradise in their newly discovered home, they were confronted by another set of oppressors from the West, who used brutal force to subject them to servitude and kill a great number of them within one night (99).

\section{Catalogue of Troops}

According to Sackey, all poetry is by "nature poetry of violent passions" (45). Violence manifesting in two or more groups fighting and competing for a common object of interest. In the Odyssey, for instance, violence was manifested in several forms. The central one had to do with numerous suitors competing for Penelope's hand in marriage in Odysseus's absence. In Two 
Thousand Seasons, we have three identifiable groups; two were busily fighting to annex the group of their fundamental human right to freedom. Symbolically the three groups can be represented on a triangle, with the Africans at the peak and the Arabs and the European missionaries at the base. In relating the catalogue of troops, numerous wars and confrontations between opposing factions are brought to the fore. Also, the narrator describes in detail the names and pedigrees of most participants in these confrontations. Sackey again explains that epic battles are represented in all their gory details (55). Between pages 21 and 23, the narrator explicitly describes the escapees of the Arab sexual onslaught and the violence meted on them in such detailed aptness that it raises eyebrows. The same vividness is used in describing the escape plan by the captured slaves.

Each group in the ensuing duet in the text had a support troop. The askaris supported the Muslims who were their masters. The westerners were also supported by some chiefs such as Atobra and Koranche. The group members, too, were presented as one force that had to contend with both sections.

Women primarily led the troops of the black people. The first battle to overturn the oppression meted out on the black people was led by various women who cunningly carried out an onslaught that brought the nefarious activities of the Islamic predators to a halt. Among them were Azania, Sekela, Nywele, Nandi, and numerous nameless others who died that night. During the period of emigration, the black people had strong team members who engaged in arm to arm combat with askaris sent by the predators to pursue them. The troop of the blacks had prominent leaders such as Nangome and Noliwe, beside the pathfinders. Again, during the inversion by the western colonisers, the black people had a strong team led by prominent leaders like Abena, Naita, Mokili, Liamba, Lini and Isanusi. The Western colonisers came with their troops. In all, some five white men and eight black men came to Anoa. With support from chiefs such as Atobra, Koranche and his courtiers, the western invaders too formed a troop. These waged wars against the black community killed "three hundred human beings in one night alone" (99). As explained, each side had a group with which it hoped to succeed in the epic battle. Again, Armah's Epic fulfils a vital requirement of an epic plot.

\section{Digressions}

Another feature of the epic plot is the calculated use of diversions in the sequence of the narrative. This takes the form of flashbacks, flash-forwards, pauses, scenes, dialogues, slow down scenes and many others to fill in missing narratives. The narrator mostly digresses either to bring out a forgotten fact or to fill in a link. Often, Two Thousand Seasons has been called a problematic text. For instance, Chinua Achebe called it "ponderous, heavy, wooden" and compared it to "a lump of concrete sitting in a place" (The Massachusset Review 28, 1987). The difficulty in Two Thousand Seasons emanates from the narrative technique of the author. The text itself is a straightforward narrative of a people's escape from bondage under Islamic rule to a new settlement where another set of colonisers from the West confronted them. Numerous digressions extend the narrative time and make the narrative quite prolonged than the story-time. It needs to be explained that the story- 
time starts after almost a quarter of the narrative time had been spent on the history and facts of the object of the narrator's musings.

Page one to page four only extend the narrative time; none of what is narrated forms a part of the story-time. Again, speaking about the exploits and prophecies of Anoa, the narrative uses exterior analepsis to reveal the exploits and achievements of that spirit. This, too, does not form a part of the narrative time (13-15). Further, the history of the caretakers from Odunton to Bonsu also falls out of the narrative time (63-66). In other words, that piece of information has no direct bearings on the story being narrated. With or without it, the story could still have been told to a successful conclusion. The digressions in Two Thousand Seasons are characteristic of the modern novel, which has the quality of "...randomness, inconsistency, deviation, omission", meant "to reflect the incoherence and incongruity of real life, in which things seldom go at any regular pace or hang fully together" (Matz 39). The narrative seldomly move in a linear progression, and this explains the tag of difficulty often associated with Armah's texts, especially, Two Thousand Seasons.

\section{The Division into Books and Cantos}

The Epic is generally divided into either 24, 12 or 6 parts, books or cantos. The Odyssey has 24 books; The Iliad has 24 books; the Aeneid has 12 books; Paradise Lost has 12 books. The division in Two Thousand Seasons is entirely different from any of the epics mentioned above. It is divided into seven parts, each with a unique subheading. The first part is subtitled "the way". The last part is subtitled "the voice". Interestingly, the middle episode, thus the fourth episode, is subtitled "the destroyers". It can be inferred that separating the 'way' from the 'voice' are the 'destroyers'. The destroyers are made up of both the Arab and western invaders. Besides, the division of the book into seven parts brings to light the spiritual interpretation of the figure seven. The world was created in six days, then on the seventh day, God rested. Koran mentions seven heavens, so the Muslim pilgrims walk around the Kaaba in Mecca seven times. In Hinduism, too, there are seven higher worlds and seven underworlds. In Buddhism, the newborn Buddha rises and takes seven steps. In African mythology, the number seven represents perfection, effectiveness and completeness. In The History of Religious Ideas, vol 1., we read that the body of the god Osiris was torn into fourteen pieces, seven each for the upper and lower Egypt. The seven-part division of this epic text can be interpreted as an ultimate handbook for Africa's liberation. All the above lead to the conclusion that Armah's text division should be read as a symbolic representation rather than mere deviation.

\section{Conclusion}

This study set out to investigate the structural devices of the plot of Two Thousand Seasons. Armah makes prudent use of anterior and posterior time to reconstruct and predict the future of African nations. It has also been observed that the author consistently invokes and acknowledges the presence of spirit beings in the execution of most activities in the text. Armah's opening 
invocation, in the form of the prologue, is a spiritual awakening of the godhead. Characteristic also is the extensive geographical travelling of the hero, which is both ideological and physical. Besides the above, three groups were identified and associated with the various catalogue of troops. It also emerged that digressions are a crucial feature of Armah's Epic. This has earned the text a problematic tag by lay readers. Finally, the divisions tow a unique formula as Two Thousand Seasons has seven-part divisions, unlike Homer's Odyssey or Iliad. The seven-section division is not a deviation as may be thought, but a deliberate attempt at symbolically using every part of the book for the benefit of the narrator. Two Thousand Seasons is, by all standards, a great epic narrative. This work has established that the plot conforms to Aristotle's definition of epic plots. I recommend future research to investigate Armah's use of the other four elements of the Epic: character, diction, thought and historical value of Two Thousand Seasons

\section{Authorial Bio}

Gladys Agyeiwaa Denkyi - Manieson is a faculty member at the Department of Communications Studies and Languages, Central University, Ghana. She is also a PhD candidate at the University of Ghana)". Her interest area includes African literary studies, film criticism, and comparative literature. She is also a member of the Linguistics Association of Ghana, African Literature Association, African Oral Literature Association. Gladys is currently the graduate student's Africa representative for the Canadian Association of African Studies.

Disclosure Statement: There are no competing interests against the publication of this article.

ORCID NUMBER: 0000-0002-5454-2329

\section{Works Cited}

Anti, Kojo Kenneth. Women in African Traditional Religion. http://www.mamiwata.com/women.html. 8/7/2018.

Anyidoho, Kofi. Literature and African Identity: The Example of Ayi Kwei Armah, in Critical Perspectives on Ayi Kwei Armah. Edited by Derek Wright, Three Continents, 1992.

Aristotle. "On The Art of Poetry." Classical Liteary Criticism, edited by T.S Dorsch, 10th ed., 
KENTE, 2021

Vol.,2 No.1

Penguin Books, 1965, pp. 29-76.

Armah, Ayi. Kwei. The Revolutionaries. 2013.

Armah, Ayi. Kwei. KMT; the House of Life. Per Ankh, 2002.

---. Osiris Rising. Per Ankh, 1995.

---. The Beautyful Ones Are Not Yet Born. Heinemann, 1968.

---. The Healers. Heinemann, 1979.

Armah, Ayi Kwei. Fragments. Collier Books, 1970.

---. Two Thousand Seasons. PER ANKH, 1973.

Ashcroft.Bill. Remembering the Future: Utopianism in African Literature. pp. 703-22.

Bernth, Lindfors. “'Armah's Histories."” Critical Perspectives on Ayi Kwei Armah., edited by Derek Wright, Three Continent, 1992.

Biebuyck, D. P. and Mateene, R. C. The Mwindo Epic of the Banyanga. University of California Press, 1969.

Biebuyck, P. Daniel. “The African Heroic Epic.” Journal of the Folklore Institute, vol. 13, no. 1, University Press., 1976, pp. 5-36.

Bird, Charlse. The Songs of Seydou Camara-Kambili. Indiana University African Studies Center, 1974.

Diabata, Massa Makan. Kola Jata. 1970.

Dzobo, Noah Komla. The Idea of God Among the Ewe of West Africa. 1976, doi:Manuscript.

Finnegan, Ruth. Oral Literature in Africa. Oxford University Press, 1970.

Hesiod. Theogony. Edited by Richard Cardwell, S, Focus Publishing/R. Pullins Co, 1987.

Homer. The Odyssey. 1614.

Horace. Ars Poetica. https://www.poetryfoundation.org/articles/69381/ars-poetica.

Kesteloot, Lilyan. “The African Epic.” African Language and Cultures, 1989, pp. 202-04.

Kunene, Mazizi. Emperor Shaka the Zulu: A Zulu Epic. Heinemann, 1979.

Lorentzon., Lief. "Ayi Kwei Armah's Epic We-Narrator." Critique: Studies in Contemporary Fiction, vol. 38, no. 3, 1997, pp. 221-34, doi:10.1080/00111619.1997.10543177.

Lovejoy, E. Paul. The Export Trade in Slave, 1600 - 1800 from Transformations in Slaves: A History of Slavery in Africa. Cambridge University Press., 2000.

Matz's., Jesse. The Modern Novel: A Short Introduction. Blackwell Publishing., 2004.

Mbiti, John S. Introduction to African Religion and Philosophy. Heinemann, 1969.

Mensah, A. .. "Style and Purpose in Armah's Two Thousand Seasons." African Literature Today, edited by Eldred Jones, James Currey, 1991.

Minchin, Elizabeth. "The Poet Appeals to His Muse: Homeric Invocations in the Context of Epic Performance." The Classical Journal., vol. 91, no. 1, 1995, pp. 25-33.

Mtshali, Khondlo. Gods, Ancestors, and Hermeneutics of Liberation in Ayi Kwei Armah's Two Thousand Seasons. Saint Mary's University., 2009, doi:10.1177/0021934707307835.

Mulokozi M, M. Fabula. The African Epic Controversy: Mkuki na Nyota Publishers, 2002, https://search.proquest.com/openview/251b5c94db8aec0c98990dc35e3288a2/1?pqorigsite $=$ gscholar \&cbl $=44908$. 
Niane, Djibril T. Sundiata, A Epic of Old Mali. Paris, 1960.

Nwahunanya, Chinyere. "A Vision of the Ideal, Armah's Two Thousand Seasons." Modern Fiction Studies SPECIAL ISSUE: POSTCOLONIAL AFRICAN FICTION, vol. 37, no. 3, 1991, pp. 549-60.

Okpewho, Isidore. Myth and Modern Fiction in Ayi Kwei Armah's Thousand Seasons. Columbia University Press, 1977.

---. The Epic in Africa. Towards a Poetics of the Oral Performance. Columbia University Press, 1979.

Sackey, Albert A. Dimensions of Comparative Literature. Sylvapress, 2010, Print.

Sekyi - Otu, Ato. “Towards Anoa...Not Back to Anoa'. The Grammar of Revolutionary Homecoming of Two Thousand Seasons." Research in African Literatures (Special Issue On Ayi Kwei Armah), vol. 18, no. 2, 1987, pp. 192-214.

Seydou, Christian. The African Epic: A Means for Defining the Genre. Edited by Katheryn Wright (translator),file:///home/Chronos/u1bdbb034f380198b93d4225f03511d515ce12be2/Downlo ads/New\%2520Folder/african\%25 20 epic/16(1) 47-68.pdf. 7/7/18.

Smart-Ngaboh, Francis. "Narrative as Tactics in Armah's Two Thousand Seasons. Matatu." FonTomfrom: Contemporary Ghanaian Literature, Theatre and Film., edited by Kofi Anyidoho and James Gibbs., Brill Rodopi, 2000, pp. 21-20.

Soyinka, Wole. Myth. Literature and the African World. Cambridge UP, 1976.

Tabone, Mark A. Rethinking Paradise: Tony Morrison and Utopia at the Millenium. Saint Louis University and John Hopkins University Press, 2016.

The Massachusset Review. Vol. 28, no. 4, The Massachusetts Review, Inc., 1987. 